\title{
Effect of Performance Management on Employees Well-Being via Perceived Job Control
}

\author{
Hooria Sattar (Corresponding Author) \\ School of Business Administration, National College of Business Administration and \\ Economics \\ 40/E1 Gulberg III, Lahore. \\ Tel: 92-(042)-357-527-166_E-mail: hooriasattar33@gmail.com
}

Lubna Khaliq

School of Business Administration, National College of Business Administration and Economics

40/E1 Gulberg III, Lahore.

Tel: 92-(042)-357-527-166_E-mail: lubnakhaliq11@gmail.com

Dr. Mattiullah Butt

School of Business Administration, National College of Business Administration and Economics

40/E1 Gulberg III, Lahore.

Tel: 92-(042)-357-527-166Ｅ-mail: drmatti@ncbae.edu.pk

Received: April 15, 2018 Accepted: May 16, $2018 \quad$ Published: May 18, 2018

doi: 10.5296/hrr.v2i1.13155 URL: https://doi.org/10.5296/hrr.v2i1.13155

\begin{abstract}
The significant amount of research attention was given to the association among HRM and well-being; but how the attention driving performance management influences well-being and what variables explain their relation has not been well discussed yet. This study investigates the relationship between performance management practices and employees well
\end{abstract}


being when perceived job control is playing the role of mediator. The Present research study addresses this relation in, educating employees working in different sectors in Lahore city as the city recruits employees from different areas of the country (Pakistan). Data was gathered from 250 employees and results show that performance management significantly influences our mediator and well-being and also the mediator (perceived job control) significantly influences the relationship between performance management practices and well-being. For future research purposes, limitations as well as future directions are also discussed in this research.

Keywords: Performance management practices, Well-being, Perceived job control

\section{Introduction}

Performance management refers to the broad range of trial, policy, dealings, and interventions deliberate to help workers improve their performance (Denisi \& Murphy, 2017). Putting into practice, PM usually includes the constant method of finding, measuring, and increasing the performance of individuals and groups in organizations (Aguinis \& Pierce, 2008), and it involves as long as both official and unofficial performances related information to workers (Selden \& Sowa, 2011). Furthermore, academics and practitioners continue to arrive at conclusions about performance management based on erroneous or obsolete information (Gorman, Cunningham, Bergman, \& Meriac, 2016).

Well-being at job plays a vital role, not only for workers, however, also for organization, the economy and the social order confined (Berry, Mirabito, \& Baun, 2010; Black, 2008; Danna \& Griffin, 1999; Jeffrey, K., Mahony, S., Michaelson, J., \& Abdallah, 2014). On the other hand, in spite of increasing stiff of study, debates prolong to focal point on dimension issues, lack of erect definition of well-being and lack of agreement on the association between well-being, HRM and stiff performance (Edgar, Geare, Halhjem, Reese, \& Thoresen, 2015; Guest, 2002; Oppenauer \& Van De Voorde, 2016; Peccei, 2004; Van De Voorde, Paauwe, \& Van Veldhoven, 2012).

We observe how one single HRM performs, performance management, relates to the well-being of employees. Our termination to learn performance management is principally aggravated by the rehabilitated notice for this perform in the literature (Buckingham \& Goodall, 2015; Cappelli \& Tavis, 2016) and the survival of preceding contradictory proof (Guest, 2002). To observe the association among performance management and well-being, insights from organization theory (Eisenhardt, 1989; Fama, 1980; Jensen \& Meckling, 1976) and stewardship theory (James H. Davis, Schoorman, \& Donaldson, 1997; Hernandez, 2012) are studied.

According to D. Guest (2002) a restricted quantity of studies contains integrated workers, behaviors and performance into an analysis of the association among HRM, and performance. As oblique in the previous investigation, these focal points mainly on dedication based attitudes or performance related to unrestricted exertion. While such, they change from investigating on worker fulfillment and wellbeing. On the additional side, but a position of HR practices be initiated to be connected, mutually with elevated performance and worker fulfillment/well-being.

The occurrence of perceived job control alternatives is connected to life contentment, maybe 
as a pointer of the significance of employment defense for general well-being. More than significant for being fulfillment that for work fulfillment and is extensively related to life contentment in all segment (Guest, 2002). According to Skinner and Baltes, "Perceived job control has been examined not only for the reason that it is motivating in itself, even though, because it predicts significant aspect of motivational, cognitive, and expressive implementation". (Abramson \& Seligman, 1978; Bandura, 1977; Peterson \& Seligman, 1984). Perceived job control is considered to be associated with, although distinguishable from, both the intention sum of organize a individual has in a condition and creature systematic estimation of above hundred studies and accomplished that a high force of perceived job control, considered as the degree of self-sufficiency or contribution, in conclusion, creation a character enjoy was related with lofty level of profession satisfaction, managerial obligation, incentive, concert and low level of objective and psychological symptom of anxiety.

\section{Theoratical Background and Hypothesis}

\subsection{Performance Management Practices and Perceived Job Control}

Perceived job control be consequently replicated within workers' perceptions of autonomy and the effect and was behaved in a manner as such in current studies. Furthermore, In the employees' perceived job control dispositional and situational factors provide results, although it is beyond the scale of the current studies to calculate the comparative effect of these factors on perceived control of job. In perceive job control many workers are dispossitionally in comparision to others (Rotter, 1966), while on other side post layoff working environment are more promoting control on workers than others (Mishra, Spreitzer, \& Mishra, 1998).

Workers with a great mental approach provide low turnover purpose, family work divergence and stress (Kossek, Lautsch, \& Eaton, 2006). The strategies about boundary management maintain a high level of assimilation were optimistically linked to family work divergence. Research helps to provide difference between depiction of elasticity use and the workers mental practices with elasticity (psychosomatic job control provides ability to individual that how, when and where deal the situation in a good manner and also not forget the separate work family boundries). Officially used the flexible policy not be confused by getting experience at home practice, or by the mentally satisfaction about work control or work family boundries (Kossek et al., 2006).

Current research has started to define that how and when limited foundation persuade the management policy and practices of performance. For example, Cogin and Williamson (2014) exhibit that in restricted surroundings characterized by superior rank of ecological ambiguity, superior levels of localization of HR practices were related with higher levels of supplementary performance of an organization. The organizational detachment between the host and home nations has also been shown to collision on the standardization/localization of performance management systems (Kostova, 1999; Xu \& Shenkar, 2002). It is noteworthy that overall performance management substance such as performance appraisals, performance-related pay and even training and improvement do not feature as performance management practices interrelated with work fulfillment of the employees. 


\section{Macrothink}

There are, however, alternative views on managing people's performance (Bouskila-Yam \& Kluger, 2011; DeNisi \& Pritchard, 2006; McKenna, Richardson, \& Manroop, 2011). Some researchers (Franco-Santos, Rivera, \& Bourne, 2014; Frey, Homberg, \& Osterloh, 2013; Segal \& Lehrer, 2012; Weibel, Rost, \& Osterloh, 2010) suggest that the traditional view of performance management as conceived in HRM (Aguinis \& Pierce, 2008; Den Hartog, D. N., Boselie, P., \& Paauwe, 2004) does not fully reflect the HRM practices that may enhance employees motivation and performance management practices when a non-financial organizational purpose is presumed and human behavior is not assumed to be opportunistic. These researchers (for example Franco-Santos et al., (2014); Segal \& Lehrer (2012)) draw their ideas from insights extracted from stewardship theory research (J. H. Davis, Frankforter, Vollrath, \& Hill, 2007; James H. Davis et al., 1997; Hernandez, 2012).

H1: Performance management practices positively related to perceived job control.

\subsection{Perceived job control and Wellbeing}

Numerous studies have been devoted to the results of planning conduct. Macan (1994) determined that making plans behavior as such no matter the impact of time management schooling had a full size relationship with 'perceived job control,' which in turn became definitely associated with process pleasure and negatively to process prompted and somatic tensions. Perceived control of jobs consequently acted as a mediator in the relationship among overall performance management practices and well-being. Well-being is derived from an aggregate of the way a person presents experiences over a time period and how satisfied they may be with their life typical (Kahneman, Krueger, Schkade, Schwarz, \& Stone, 2004; Layard, 2005). Danna \& Griffin (1999) located that bad nicely being of personnel can affect their physical activities even as in organizational terms, it could have a negative effect on productivity, absenteeism, presenteeism, compensation complaints, and so forth.

By integrating self-dedication principle (Deci \& Ryan, 2012) into COR (Halbesleben, Neveu, Paustian-Underdahl, \& Westman, 2014) argue that the motivation to collect autonomy-associated assets, including job control might have the greatest effect on well-being effects. Over and above job control and social support has been broadly studied as a core work-related resources. It's been described as perceived manipulate over one's obligations and behavior in the course of the work day and involves having the choice of changing one's work environment by means of changing factors of the work task or work method (Karasek \& Jr., 1979). Longitudinal research has repeatedly established high quality effects of perceived job control on sense of intelligence (De Lange, Taris, Kompier, Houtman, \& Bongers, 2003) for an evaluation and on task performance (Bond \& Flaxman, 2006). Studies have also proven that low degrees of perceived job control relate to the impaired common sense (Bosma et al., 1997; Steptoe \& Willemsen, 2004).

H2: Perceived job control is positively related to well-being.

\subsection{Performance Management Practices and Wellbeing}

It is essential to motivate the employees, not just whether or not, however, why the organizational performances can be associated with an employees' sense of intelligence to unite their work and their various activities, as well as their general sense of humanity and well-being. The researcher believes that the perceived control of job may be an essential 
system that affect the association among the executive strategies and the satisfaction of an employee and well-being (Anderson, Coffey, \& Byerly, 2002). Another essential, but comparatively ignored the part that manipulates the employees' capability to assimilate their job and their relatives are the general nature of the jobs they execute. Especially, job circle researcher's discussed that the employees' job self determination the capacity to determine when, where, and the way that the work task is to be achieved (Bailyn, 1993; Clark, 2001) mostly focused on the employee's well being. According to (Greenberger \& Strasser, 1986) and others (Ganster, Fox, \& Dwyer, 2001), employees are influenced to searching to be in command over their surroundings, and this kind of control is essential to their employees' well-being (Bond \& Bunce, 2003; Bosma et al., 1997).

Discussion does now not review the organizational performance that exerts pressure to engage in working for long hours, however, it is ordinary to make inquiries what these could be. Particularly, it looks achievable that excessive dedication or excessive overall performance management practices make a wrong effect on individual's personal life of the workers, to the point that they may be considered to show extra discretionary exertion to chase the organizational desires. Performance management practices to bad overflow had been varying over this time.

We additionally emphasize the significance of the well-being of academics for the achievement of their scholarly project, the results of universities and their contributions to society as an entire. Furthermore, the emotions activate individuals' devotion, as well as their dedication to finish duties, inspire problem declaration, and are seeking to get better average process in general performance (Chiang \& Jang, 2008; Hwang, 2005; Yen, Lin, \& Tai, 2004).

\section{H3: Performance management is positively related to well-being.}

\subsection{Perceived Job Control as a Mediator}

Institutional emotional have theorized perceived job control in two associated but dissimilar means that are not commonly unrelated (Spector, 1986; Greenberger et al., 1989). One origination, the "self-determination" framework, recommends that an individual's wisdom of control relies upon whether they see their deeds to be self-determined against forced, otherwise to utilize (DeCharms, 1968), regardless of while they consider themselves to be "origins" who start deeds as opposed to "pawns" who merely respond to their surroundings. To the degree that survivors observe that they have a higher amount of good judgment power or effort to their job accomplishments, they are possibly going to practice higher level of perceived control of job.

Perceived Job control increases intellectual liveliness too, because of its strong intellectual factor (Frese \& Zapf, 1994). (Hoppe, 2011) discovers that employee job control has direct and indirect impacts on impeded well-being among local employees but not among migrant employees. As well, another two studies on migrants in Northern European nations have revealed that employee job control functions as an asset between citizens, however, not among migrant employees in Sweden (Rosmond, Lapidus, \& Björntorp, 1998) and Britain (Wadsworth et al., 2007), correspondingly.

We claim that these outcomes may be strengthened when Higher level of performance work framework are realized with anappropriate sum of employee job control, or judgment known 


\section{Macrothink}

to staff in defining in which way we actualize working duties and tasks (Karasek \& Jr., 1979). Hence, we claim that the consequence of higher level of performance work framework on employee stress has to be measured in view of employee's job control. For instance, a worker who has a small amount of control over in what manner and at what time to do his/her work is to be expected to experience higher psychological consequences as of the perceived job demands linked with a higher level of performance work framework than another member of staff seeing the similar requirement who has the scope to exercise additional individual judgment.

H4: Perceived job control mediates the relationship between performance management and wellbeing.

\section{Theoratical Framework}

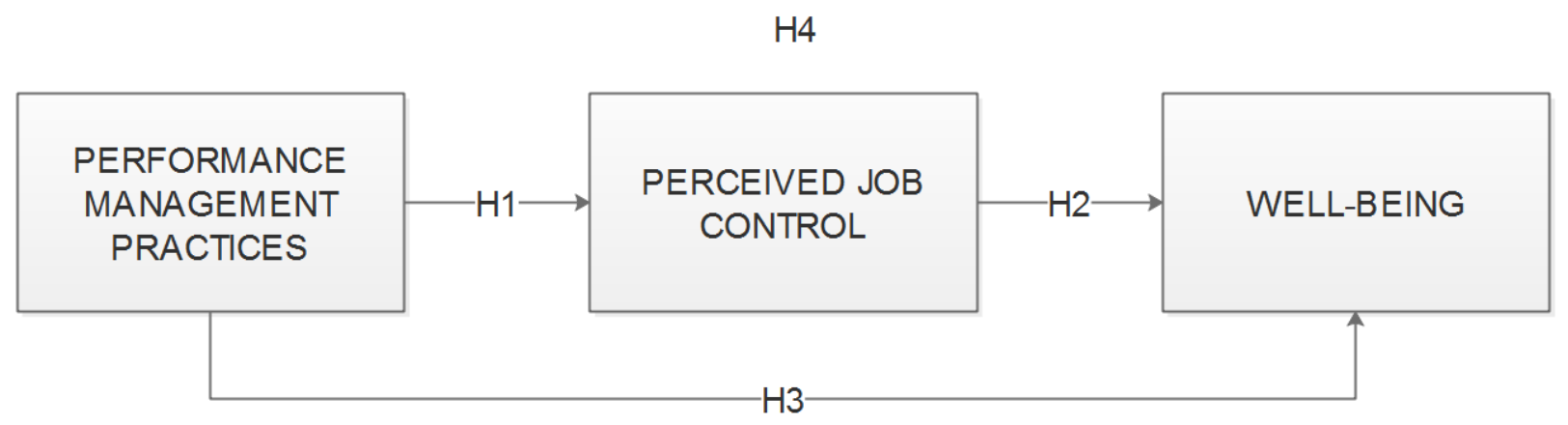

\section{Methodology}

\subsection{Sample and Procedure}

For the survey on performance management and well-being in different companies belonging to different sectors of Lahore, Pakistan. 320 questionnaires were distributed and 250 were completed and returned, resulting in a response rate of $78 \%$. Of these employees, 123 males (49.2\%) and 127 females (50.8\%). We conducted our study with the help of convenience sampling. Their average age between the interval (31-40) years was $3.02(\mathrm{SD}=1.305)$, and their mean organization tenure in between the interval (3-5) years was $3.00(\mathrm{SD}=1.674)$.

\subsection{Measures}

\subsubsection{Performance Management Practices}

The Performance management system independent variable was measured by using the scale of Gomez-Mejia et al. (2010) consisting of seven items. A sample item is "My institution uses specific performance indicators to monitor performance,". The scale ranged from 1 'strongly disagree' to 7 'strongly agree'.

\subsubsection{Perceived Job Control}

The perceived job control is a mediator between performance management practices and well-being. Each item was measured from Kinman \& Wray (2013) on a seven-point Likert scale ranging from 1 'strongly disagree' to 7 'strongly agree'. A sample item is "I have a choice in deciding how I do my work". 


\subsubsection{WellBeing}

Well-being is the dependent variable in our study. This variable is measured using two dimensions of the well being, positive (vitality) and negative (relational stress). Vitality is measured using the three-items validated by Porath, Spreitzer, Gibson, \& Garnett (2012) and relational stress was measured by three items developed by Cousins et al. (2004). The sample items are "I feel alive and vital at work," and "Relationships at work are strained (artificial)". The scale ranged from 1 'strongly disagree' to 7 'strongly agree'.

\section{Results}

Table 1 presents the means, standard deviations, and correlations along with the key variables. The independent variable was not significant and not correlated, perceived job control was a mediator and highly significant and highly correlated $(r=.471)$, and the well-being was the dependent variable and was also highly correlated $(\mathrm{r}=.789)$.

Table 1. Descriptive statistics and correlations

\begin{tabular}{|c|c|c|c|c|c|c|c|c|c|c|c|}
\hline & & $\mathrm{M}$ & S.D & 1 & 2 & 3 & 4 & 5 & 6 & 7 & 8 \\
\hline 1 & Age & 3.02 & 1.305 & - & & & & & & & \\
\hline 2 & Qualification & 2.89 & 1.034 & $.338^{* *}$ & _- & & & & & & \\
\hline 3 & $\begin{array}{l}\text { Income (In } \\
\text { Thousands) }\end{array}$ & 3.30 & 1.679 & $.643^{* *}$ & $.447^{* *}$ & - & & & & & \\
\hline 4 & Tenure & 3.00 & 1.674 & $.785^{* *}$ & $.278^{* *}$ & $.696^{* *}$ & - & & & & \\
\hline 5 & Experience & 3.21 & 1.854 & $.805^{* *}$ & $.299^{* *}$ & $.760^{* *}$ & $.884^{* *}$ & - & & & \\
\hline 6 & PMP & 4.56 & 1.086 & .019 & .064 & -.017 & -.046 & -.036 & (.781) & & \\
\hline 7 & $\mathrm{PJC}$ & 4.57 & 1.212 & .083 & -.010 & -.038 & -.014 & .002 & $.471^{* *}$ & $(.774)$ & \\
\hline 8 & WB & 4.50 & .967 & $.209^{* *}$ & .088 & -.016 & .092 & .101 & $.461^{* *}$ & $.468^{* *}$ & (.789) \\
\hline
\end{tabular}

Note: $N=250$. M, Mean; S.D, Standard deviation; PMP, Performance management practices; PJC, Perceived job control; WB, Well-being3. c Qualification: ( $1=$ Intermediate; $2=$ bachelors; 3=Masters; 4= MS/M. Phil; 5=PhD). d Income: (1= Less than 16; 2=16-25; 3=26-40; 4= $41-60 ; 5=61-90 ; 6=91-130 ; 7=131-200 ; 8=$ More than 200). Cronpach Alpha values given in paranthesis.

**. Correlation is significant at the 0.01 level (1-tailed).

\subsection{Hypothesis Testing}

\subsubsection{Regression and Mediation Analysis}

For mediation analysis, Preacher Haye's Mediation with Bootstrapping $(n=5000)$ was used. The direct effect of Performance management practices on well-being fitted significantly with $\left(\beta=.461, \mathrm{R}^{2}=.2128, \rho=.000, \mathrm{CI}=.3120, .5097\right)$ supporting $\mathrm{H} 3$ showing that Performance management practices significantly affects creativity. The $\mathrm{p}$ values being less than 0.01 and 
the $95 \%$ confidence intervals did not contain 0 between higher and lower values showing the significance. Then regression between the PMP and Perceived job control was also significant $\left(\beta=.471, \mathrm{R}^{2}=.2218, \rho=.000, \mathrm{CI}=.4027, .6490\right)$ supporting $\mathrm{H} 1$ showing that $\mathrm{PFP}$ significantly effects Perceived job control $\left(\beta=.310, \mathrm{R}^{2}=.2935, \rho=.0000, \mathrm{CI}=.1617, .3522\right)$. Then the regression between perceived job control and well-being was also significant $(\beta$ $\left.=.322, \mathrm{R}^{2}=.2935, \rho=.0000, \mathrm{CI}=.1694, .3821\right)$ supporting $\mathrm{H} 2$ showing that perceived job control effects well-being.

\begin{tabular}{llllll}
\hline Testing paths & B & SE & P & $95 \% \mathrm{CI}$ & B \\
& (unstanderdized) & $(\beta)$ & & & (Standerdized) \\
\hline
\end{tabular}

WB (Well-Being)

$\mathrm{R}^{2}=.2128, \mathrm{~F}(1.00,248)=67.0423, \rho=.0000$

$\begin{array}{llllllll}\text { PMP } & \text { (Performance } & .4109 & .0502 & .0000 & .3120, .5097 & .461\end{array}$

Management Practices)

PJC (Perceived Job Control)

$\mathrm{R}^{2}=.2218, \mathrm{~F}(1,248)=70.7009, \rho=.0000$

$\begin{array}{lllllll}\text { PMP(Performance } & .5259 & .0625 & .0000 & .4027, .6490 & .471\end{array}$

Management Practices)

WB (Well-Being)

$\mathrm{R}^{2}=.2935, \mathrm{~F}(2,247)=51.3148, \rho=.0000$

$\begin{array}{llllllll}\text { PMP } & \text { (Performance } & .2570 & .0484 & .0000 & .1617, .3522 & .310\end{array}$

Management Practices)

$\begin{array}{llllllll}\text { PJC } & \text { (Perceived Job } & .2758 & & .0540 & .0000 & .1694, .3821 & .322\end{array}$

Control)

Total

PMP direct effect on WB through (path c) the standardized $\beta=.461$, PMP indirect effect on WB through (path c) the standardized $\beta=.471$, PMP effect on PJC through (path a) the standardized $\beta=.415$, PJC effect on WB through (path $b$ ) the standardized $\beta=.322$ and the total through (path $\left.\mathrm{a}^{*} \mathrm{~b}\right) \beta=.1517$.

\section{Discussion}

Firstly, we extend the previous HRM research by suggesting that the basic assumptions of different HRM practices may enlighten why their association with well-being was previously found inconclusive. As suggested by Pfeffer and Sutton (2006) numerous, often concealed, 
assumptions (and internalized theories about what works and what does not work in organizations) motivate the mental models of senior leaders and inform the design of management practices (e.g. Compensation and performance management).

Secondly, our research donates to the debate on the performance 'enabling' role of HRM (Paauwe, 2009). In his review of the HRM Performance literature, (Paauwe, 2009) suggests that performance is more expected to transpire when organizations take care of their employees safeguarding they are impartially treated and their well-being is considered. The current study recommends that a directive approach focused on maximizing performance influencing behavior as agreed by agency theory appears to counter academics' well-being.

\section{Limitation}

This study is not free from limitations. For instance, based on our theoretical background, we selectively focussed on a set of variables to comprise in our theoretical model. This supports regulator for perceived job control and two groups of well-being (happiness, well-being assessed in term of vitality and relationship well-being assessed in terms of relational stress). This approach supplements to the previous indication base which has used these constructs (Kinman, Jones, \& Kinman, 2006; Peccei, 2004; Van De Voorde et al., 2012). Though, while shortening our analysis, it leaves a variety of other variables uncertified in terms of work experiences and well-being outcomes. Therefore, there is an opportunity for the examination of the variety of other variables at play, such as indices of work experience; job security, wage-effort and experience of change. Furthermore, this paper stresses on two indices of well-being which, although highlighted in existing literature as persistent concerns within the context of academia, need to be extended to a more comprehensive range.

Given the confronted nature of the concepts of well-being and performance and the nature of the HRM practices applied to boost performance and stimulate well-being this field is in need of considerable concept explanation (Suddaby, 2010) to clearly define the definitional consistency, the scope and relational nature of the constructs under study. In addition, as proposed by (Peccei, 2004) there is a need to continue to apply multi-level analysis models to achieve an improved understanding of the relationships between the constructs under study.

\section{Conclusion}

As the boost of attention on organizational supervision during these years, HRM plays a supplementary job to run the association, such as the belongings of HRM on novelty, 'new way of effective principle' for running associations. The performance management system, as a field of study, is a popular matter in HRM over time. It is essential for corporation to plan, supervise and recompense the performance. As did so, the productivity of the company would be residential and also revenue would be improved as well through managing the entire procedure of performance management, such as construct aims, examined opinion and appraising performance.

The intention of this study is to examine the performance management system indicator and their relation to the performance of the employee is based on Perceived job control, positively related to well-being as performance management is positively related to well-being. Therefore, perceived job control mediates the relationship between performance management and well-being. At last the main purpose is to figure out the nature of the association among 
performance management system and its effect on employees' well-being via perceived job control and to make a termination, also to expand a place of commendations.

Accordingly, the study complements to the more pragmatic proof that supports the estimation about the association between performance management system and employee performance. On the other hand, concerning the various limitations of this study, in which the major limitation is: while based on our theoretical background, we selectively focused on a set of variables to include in our conceptual model. This aids control of perceived job control and two categories of well-being (happiness, well-being assessed in term of vitality and relationship well-being assessed in terms of relational stress). However, while facilitating our analysis, it leaves a range of other variables untested in terms of work experiences and wellbeing outcomes. Therefore, there is scope for the examination of the range of other variables at play, such as indices of work experience; job security, wage-effort and experience of change. Additionally, this paper focuses on two indices of well-being which, although highlighted in current literature as pressing concerns within the context of academia, need to be extended to a more comprehensive range.

Given the contested nature of the constructs of well-being and performance and the nature of the HRM practices applied to encourage performance and promote well-being this field is in need of considerable concept clarification to clearly delineate the definitional coherence, the scope and relational nature of the constructs under study. In addition, there is a need to continue to apply multilevel analysis models to achieve an enhanced understanding of the relationships between the constructs under study.

\section{Acknowledgement}

I would like to thank Miss Sidra Rehman and Mr. Tashfeen who supported me in this paper. Also this research would not be possible without the support of my friends and family.

\section{References}

Abramson, L. Y., \& Seligman, M. E. P. (1978). Learned helplessness in humans: Critique and reformulation. Journal of Abnormal Psychology, 87(1), 49-74. https://doi.org/10.1037//0021-843X.87.1.49

Aguinis, H., \& Pierce, C. A. (2008). Enhancing the relevance of organizational behavior by embracing performance management research. Journal of Organizational Behavior, 29(1), 139-145. https://doi.org/10.1002/job.493

Anderson, S. E., Coffey, B. S., \& Byerly, R. T. (2002). Formal organizational initiatives and informal workplace practices: Links to work-family conflict and job-related outcomes. Journal of Management. https://doi.org/10.1016/S0149-2063(02)00190-3

Bailyn, L. (1993). Breaking the Mold. Free press.

Bandura, A. (1977). Self efficacy: Toward a unifing theory of behavioral change. Psychological Review, 84(2), 191-215.

Berry, L. L., Mirabito, A. M., \& Baun, W. B. (2010). What's the Hard Return on Employee Wellness Programs? Harvard Business Review, 12(December), 1-17.

Black, A. (2008). working for a healthier tommorrow. London. 
Bond, F. W., \& Bunce, D. (2003). The Role of Acceptance and Job Control in Mental Health, Job Satisfaction, and Work Performance. Journal of Applied Psychology, 88(6), 1057-1067. https://doi.org/10.1037/0021-9010.88.6.1057

Bond, F. W., \& Flaxman, P. (2006). The Ability of Psychological Flexibility and Job Control to Predict Learning, Job Performance, and Mental Health. Journal of Organizational Behavior Management, 26(1-2), 113-130. https://doi.org/10.1300/J075v26n01

Bosma, H., Marmot, M. G., Hemingway, H., Nicholson, A. C., Brunner, E., \& Stansfeld, S. a. (1997). Low job control and risk of coronary heart disease in Whitehall II (prospective cohort) study. BMJ, 314(7080), 558-558. https://doi.org/10.1136/bmj.314.7080.558

Bouskila-Yam, O., \& Kluger, A. N. (2011). Strength-based performance appraisal and goal setting. Human Resource Management Review, 21(2), 137-147. https://doi.org/10.1016/j.hrmr.2010.09.001

Buckingham, M., \& Goodall, A. (2015). Summary for Policymakers. In Intergovernmental Panel on Climate Change (Ed.), Climate Change 2013 - The Physical Science Basis (Vol. 2015, pp. 1-30). Cambridge: Cambridge University Press. https://doi.org/10.1017/CBO9781107415324.004

Cappelli, P., \& Tavis, A. (2016). The Performance Management Revolution.

Chiang, C. F., \& Jang, S. C. (Shawn). (2008). The Antecedents and Consequences of Psychological Empowerment: The Case of Taiwan's Hotel Companies. Journal of Hospitality and Tourism Research, 32(1), 40-61. https://doi.org/10.1177/1096348007309568

Clark, S. C. (2001). Work Cultures and Work/Family Balance. Journal of Vocational Behavior, 58(3), 348-365. https://doi.org/10.1006/jvbe.2000.1759

Cogin, J. A., \& Williamson, I. O. (2014). Standardize or customize: The interactive effects of HRM and environment uncertainty on MNC subsidiary performance. Human Resource Management, 53(5), 701-721. https://doi.org/10.1002/hrm.21602

Cousins, R., Mackay, C. J., Clarke, S. D., Kelly, C., Kelly, P. J., \& McCaig, R. H. (2004). "Management Standards" and work-related stress in the UK: Practical development. Work and Stress. https://doi.org/10.1080/02678370410001734322

Danna, K., \& Griffin, R. W. (1999). Health and Well-Being in the Workplace: A Review and Synthesis of the Literature. Journal of Management, 25(3), 357-384. https://doi.org/10.1177/014920639902500305

Davis, J. H., Frankforter, S., Vollrath, D., \& Hill, V. (2007). An Empirical Test of Stewardship Theory. Journal of Business and Leadership: Research, Practice, and Teaching, 3(1), 40-50.

Davis, J. H., Schoorman, F. D., \& Donaldson, L. (1997). TOWARD A STEWARDSHIP THEORY OF MANAGEMENT. Academy of Management Review, 22(1), 20-47. https://doi.org/10.5465/AMR.1997.9707180258

De Lange, A. H., Taris, T. W., Kompier, M. A. J., Houtman, I. L. D., \& Bongers, P. M. (2003). "The Very Best of the Millennium": Longitudinal Research and the Demand-Control-(Support) Model. Journal of Occupational Health Psychology, 8(4), 282-305. https://doi.org/10.1037/1076-8998.8.4.282

DeCharms, R. C. (1968). Construction \& Validation of Main Psychological Needs Scale. 
American Journal of Applied Psychology, 5(1), 7-11. https://doi.org/10.12691/ajap-5-1-2

Deci, E. L., \& Ryan, R. M. (2012). Motivation, Personality, and Development Within Embedded Social Contexts: An Overview of Self-Determination Theory. The Oxford handbook of Human Motivation. Oxford University Press. https://doi.org/10.1093/oxfordhb/9780195399820.013.0006

Den Hartog, D. N., Boselie, P., \& Paauwe, J. (2004). Performance management: A model and research agenda. Applied Psychology, 53(4), 556-569. https://doi.org/10.1111/j.1464-0597.2004.00188.x

Denisi, A. S., \& Murphy, K. R. (2017). Performance appraisal and performance management: 100 years of progress? Journal of Applied Psychology, 102(3), 421-433. https://doi.org/10.1037/ap10000085

DeNisi, A. S., \& Pritchard, R. D. (2006). Performance Appraisal, Performance Management and Improving Individual Performance: A Motivational Framework. Management and Organization Review, 2(2), 253-277. https://doi.org/10.1111/j.1740-8784.2006.00042.x

Edgar, F., Geare, A., Halhjem, M., Reese, K., \& Thoresen, C. (2015). Well-being and performance: measurement issues for HRM research. International Journal of Human Resource Management, 26(15), 1983-1994. https://doi.org/10.1080/09585192.2015.1041760

Eisenhardt, K. M. (1989). Agency Theory: An Assessment and Review. The Academy of Management Review, 14(1), 57. https://doi.org/10.2307/258191

Fama, E. F. (1980). Agency Problems and the Theory of the Firm. Journal of Political Economy, 88(2), 288-307. https://doi.org/10.1086/260866

Franco-Santos, M., Rivera, P., \& Bourne, M. (2014). Performance management in UK Higher Education institutions.

Frese, M., \& Zapf, D. (1994). Action as the core of work psychology: A German approach. Handbook of Industrial and Organizational Psychology, Vol. 4 (2nd Ed.), (JANUARY 1994), 271-340.

Frey, B. S., Homberg, F., \& Osterloh, M. (2013). Organizational Control Systems and Pay-for-Performance in the Public Service. Organization Studies, 34(7), 949-972. https://doi.org/10.1177/0170840613483655

Ganster, D. C., Fox, M. L., \& Dwyer, D. J. (2001). Explaining employees' health care costs: A prospective examination of stressful job demands, personal control, and physiological reactivity. Journal of Applied Psychology, 86(5), 954-964. https://doi.org/10.1037//0021-9010.86.5.954

Gomez-Mejia, L. R., Berrone, P., \& Franco-Santos, M. (2010). Compensation and organizational performance: Theory, research and practice (1st ed.). Routledge.

Gorman, C. A., Cunningham, C. J. L., Bergman, S. M., \& Meriac, J. P. (2016). Time to change the bathwater: Correcting misconceptions about performance ratings. Industrial and Organizational Psychology, 9(2), 314-322. https://doi.org/10.1017/iop.2016.18

Greenberger, D. B., \& Strasser, S. (1986). Development and Application of a Model of Personal Control in Organizations. Academy of Management Review, 11(1), 164-177. https://doi.org/10.5465/AMR.1986.4282657 
Guest, D. (2002). Human Resource Management, Corporate Performance and Employee Wellbeing: Building the Worker Into Hrm. The Journal of Industrial Relations, 44(3), 335-358. https://doi.org/10.1111/1472-9296.00053

Halbesleben, J. R. B., Neveu, J.-P., Paustian-Underdahl, S. C., \& Westman, M. (2014). Getting to the "COR." Journal of Management, 40(5), 1334-1364. https://doi.org/10.1177/0149206314527130

Hernandez, M. (2012). Toward an Understanding of the Psychology of Stewardship. Academy of Management Review, 37(2), 172-193. https://doi.org/10.5465/amr.2010.0363

Hoppe, A. (2011). Psychosocial working conditions and well-being among immigrant and German low-wage workers. Journal of Occupational Health Psychology, 16(2), 187-201. https://doi.org/10.1037/a0021728

Hwang, P. C. (2005). The effects of transformational and transactional leader behaviors on psychological empowerment and service oriented citizenship behaviors: a model and test of potential differences between full-time and part-time restaurant employees. Journal of Tourism and Leisure Studies, 11, 233-258.

Jeffrey, K., Mahony, S., Michaelson, J., \& Abdallah, S. (2014). Well-being at work: A review of the literatureNo Title. London: New Economics Foundation.

Jensen, M. C., \& Meckling, W. H. (1976). Theory of the Firm: Managerial Behavior, Agency Costs and Ownership Structure. Journal of Financial Economics, 3(4), 305-360. https://doi.org/http://dx.doi.org/10.1016/0304-405X(76)90026-X

Kahneman, D., Krueger, A. B., Schkade, D., Schwarz, N., \& Stone, A. (2004). Toward National Well-Being Accounts. American Economic Review, 94(2), 429-434. https://doi.org/10.1257/0002828041301713

Karasek, R. A., \& Jr. (1979). Job Demands, Job Decision Latitude, and Mental Strain: Implications for Job Redesign. Administrative Science Quarterly, 24(2), 285. https://doi.org/10.2307/2392498

Kinman, G., Jones, F., \& Kinman, R. (2006). The well-being of the UK academy, 1998-2004. Quality in Higher Education, 12(1), 15-27. https://doi.org/10.1080/13538320600685081

Kinman, G., \& Wray, S. (2013). Higher stress: A survey of stress and well-being among staff in higher education. Retrieved from https://www.ucu.org.uk/media/5911/Higher-stress-a-survey-of-stress-and-well-being-amongstaff-in-higher-education-Jul-13/pdf/HE_stress_report_July_2013.pdf

Kossek, E. E., Lautsch, B. A., \& Eaton, S. C. (2006). Telecommuting, control, and boundary management: Correlates of policy use and practice, job control, and work-family effectiveness. Journal of Vocational Behavior, 68(2), 347-367. https://doi.org/10.1016/j.jvb.2005.07.002

Kostova, T. (1999). Transnational transfer of strategic organizational practices: A contextual perspective. Academy of Management Review. https://doi.org/10.5465/AMR.1999.1893938

Layard, R. (2005). Happiness: Lessons from a New Science. New York: Penguim Press, 3491. https://doi.org/10.1007/s10902-005-0934-2

Macan, T. H. (1994). Time management: Test of a process model. Journal of Applied Psychology, 79(3), 381-391. https://doi.org/10.1037/0021-9010.79.3.381 
McKenna, S., Richardson, J., \& Manroop, L. (2011). Alternative paradigms and the study and practice of performance management and evaluation. Human Resource Management Review, 21(2), 148-157. https://doi.org/10.1016/j.hrmr.2010.09.002

Mirabito, A. M., \& Berry, L. L. (2015). You Say You Want a Revolution? Drawing on Social Movement Theory to Motivate Transformative Change. Journal of Service Research, 18(3), 336-350. https://doi.org/10.1177/1094670515582037

Mishra, K. E., Spreitzer, G. M., \& Mishra, A. K. (1998). Preserving Employee Morale during Downsizing. Sloan Management Review, 39(2), 83-95. https://doi.org/10.1225/SMR035

Oppenauer, V., \& Van De Voorde, K. (2016). Exploring the relationships between high involvement work system practices, work demands and emotional exhaustion: a multi-level study. The International Journal of Human Resource Management, 1-27. https://doi.org/10.1080/09585192.2016.1146321

Paauwe, J. (2009). HRM and Performance: Achievements, Methodological Issues and

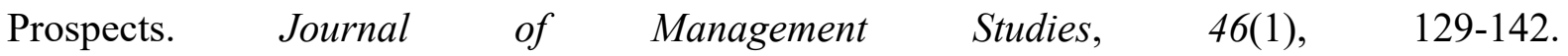
https://doi.org/10.1111/j.1467-6486.2008.00809.x

Peccei, R. (2004). Human Resource Management and the Search for the Happy Workplace. Inaugural Address to the Rotating Chair for Research in Organisation and Management in the Faculty of Economics. Retrieved from internal-pdf:/eia-2004-021-org-0301543936/EIA-2004-021-ORG.pdf\%5CnERIM Electronic Series Portal: http://hdl.handle.net/1765/1

Peterson, C., \& Seligman, M. E. (1984). Causal explanations as a risk factor for depression: Theory and evidence. Psychological Review, 91(3), 347-374. https://doi.org/10.1037/0033-295X.91.3.347

Pfeffer, J., \& Sutton, R. I. (2006). Profiting from evidence - based management. Strategy \& Leadership, 34(2), 35-42. https://doi.org/10.1108/10878570610652617

Porath, C., Spreitzer, G., Gibson, C., \& Garnett, F. G. (2012). Thriving at work: Toward its measurement, construct validation, and theoretical refinement. Journal of Organizational Behavior, 33(2), 250-275. https://doi.org/10.1002/job.756

Ramsay, H., Scholarios, D., \& Harley, B. (2000). Employees and High-Performance Work Systems: Testing inside the Black Box. British Journal of Industrial Relations, 38(4), 501-531. https://doi.org/10.1111/1467-8543.00178

Rosmond, R., Lapidus, L., \& Björntorp, P. (1998). A cross-sectional study of self-reported work conditions and psychiatric health in native Swedes and immigrants. Occupational Medicine, 48(5), 309-314. https://doi.org/10.1093/occmed/48.5.309

Rotter, J. B. (1966). Generalized expectancies for internal versus external control of reinforcement. Psychological Monographs. https://doi.org/10.1037/h0092976

Segal, L., \& Lehrer, M. (2012). The Institutionalization of Stewardship: Theory, Propositions, and Insights from Change in the Edmonton Public Schools. Organization Studies, 33(2), 169-201. https://doi.org/10.1177/0170840611433994

Sselden, S., \& Sowa, J. E. (2011). Performance Management and Appraisal in Human Service Organizations: Management and Staff Perspectives. Public Personnel Management, 40(3), 


\section{Macrothink}

251-264. https://doi.org/10.1177/009102601104000305

Steptoe, A., \& Willemsen, G. (2004). The influence of low job control on ambulatory blood pressure and perceived stress over the working day in men and women from the Whitehall II $\begin{array}{lll}\text { cohort. Journal of Hypertension, 22(5), 915-920. } & \text {. }\end{array}$ https://doi.org/10.1097/00004872-200405000-00012

Suddaby, R. (2010). Editor's comments: Construct clarity in theories of management and organization. Academy of Management Review. https://doi.org/10.5465/AMR.2010.51141319 Van De Voorde, K., Paauwe, J., \& Van Veldhoven, M. (2012). Employee Well-being and the HRM-Organizational Performance Relationship: A Review of Quantitative Studies. International Journal of Management Reviews, 14(4), 391-407. https://doi.org/10.1111/j.1468-2370.2011.00322.x

Wadsworth, E., Dhillon, K., Shaw, C., Bhui, K., Stansfeld, S., \& Smith, A. (2007). Racial discrimination, ethnicity and work stress. Occupational Medicine, 57(1), 18-24. https://doi.org/10.1093/occmed/kq1088

Weibel, A., Rost, K., \& Osterloh, M. (2010). Pay for Performance in the Public Sector--Benefits and (Hidden) Costs. Journal of Public Administration Research and Theory, 20(2), 387-412. https://doi.org/10.1093/jopart/mup009

$\mathrm{Xu}, \mathrm{D}$., \& Shenkar, O. (2002). Institutional Distance and the Multinational Enterprise. The Academy of Management Review, 27(4), 608. https://doi.org/10.2307/4134406

Yen, H. R. ;Lin. Y. L. ;Tai. S. ., Lin, Y. L., \& Tai, S. . (2004). The Impacts of Service Climate on Service-Oriented Citizenship Behavior-The Mediating Roles of Psychological Empowerment an Role Definition. Management Review (Taiwan), 財團法人光華管理策進基 金會, 23(1), 25-48. Retrieved from http://nthur.lib.nthu.edu.tw/handle/987654321/61624

\section{Copyright Disclaimer}

Copyright for this article is retained by the author(s), with first publication rights granted to the journal.

This is an open-access article distributed under the terms and conditions of the Creative Commons Attribution license (http://creativecommons.org/licenses/by/3.0/). 